\title{
Faktor Yang Berpengaruh Terhadap Perilaku Merokok Konvensional dan Elektrik Pada Remaja Di Kota Denpasar
}

\author{
Ni Luh Putu Devhy ${ }^{1}$, A.A Istri Dalem Hana Yundari ${ }^{2}$ \\ Stikes Wira Medika PPNI Bali
}

\begin{abstract}
Abstrak
Latar Belakang: Jumlah remaja yang merokok elektrik khususnya pada siswa SMA semakin meningkat. Berdasarkan penelitian rokok elektrik memiliki bahaya yang sama dengan rokok konvensional, seperti menimbulkan kecanduan, penyakit berbahaya dan mengganggu perkembangan otak. Penelitian ini bertujuan menilai proporsi siswa SMA swasta yang merokok elektrik dan faktor yang memengaruhinya.

Metode: Rancangan penelitian ini adalah cross-sectional study yang dilaksanakan di suatu SMA swasta di Kota Denpasar selama 3 bulan dari Januari sampai Maret 2017. Sampel dipilih secara keseluruhan sebanyak 174 orang. Data dikumpulkan menggunakan angket. Analisis data untuk menilai faktor yang memengaruhi perilaku merokok elektrik menggunakan poisson regresi.

Hasil: Berdasarkan hasil penelitian rata-rata umur subyek adalah 16 tahun dan semuanya berjenis kelamin laki-laki. Proporsi siswa yang pernah mencoba-coba menggunakan rokok elektrik sebesar 61,38 \% (72 orang) dan yang tetap atau aktif merokok elektrik sebesar 25,29\% (44 orang). Berdasarkan hasil analisis, faktorfaktor yang mempengaruhi merokok elektrik pada Siswa SMA swasta di Denpasar adalah siswa yang tidak percaya merokok berbahaya terhadap kesehatan berpeluang 2,8 kali untuk merokok elektrik secara aktif dibandingkan yang percaya $(95 \%$ CI 1,6-4,8). Siswa yang mempunyai keluarga merokok berpeluang 2,5 kali untuk merokok elektrik dibandingkan yang tidak punya, serta siswa yang mempunyai teman merokok berpeluang 2,6 kali untuk merokok elektrik dibandingkan yang tidak punya.
\end{abstract}

Kesimpulan: Perilaku merokok elektrik secara aktif pada siswa SMA swasta di Denpasar tergolong tinggi. Ketidakpercayaan terhadap bahaya rokok terhadap kesehatan, adanya keluarga dan teman yang merokok terbukti sebagai faktor. 
Untuk itu penting edukasi yang dapat meyakinkankan mereka tentang bahaya rokok elektrik dan intervensi melalui pendekatan keluarga serta teman sebaya.

Kata Kunci: Merokok elektrik, ketidakpercayaan terhadap bahaya rokok, Keluarga merokok, Teman merokok.

\author{
Alamat Koresponden : Jl. Kecak No.9A Gatot Subroto Timur \\ Email : : deevhy@gmail.com, hana.yundari@gmail.com
}

\title{
1. PENDAHULUAN
}

Perilaku merokok merupakan puncak permasalahan kesehatan di seluruh dunia, baik dari segi penyebab kematian di dunia dan jumlah kematian mencapai 500 juta orang per tahun. Merokok tidak hanya berdampak pada orang yang merokok (perokok aktif) tetapi juga pada orang tidak merokok yang berada disekitar para perokok (perokok pasif) atau dikenal juga dengan istilah secondhand smoker. Laporan WHO tahun 2009 berjudul The Global Tobacco Epidemic menyebutkan bahwa diperkirakan rokok tembakau turut menyebabkan kematian lebih dari 5 juta orang di seluruh dunia setiap tahun dan umumnya terjadi di negara-negara dengan pendapatan perkapita rendah hingga sedang. Jika dibiarkan, pada tahun 2030 rokok diperkirakan akan membunuh lebih dari 8 juta orang diseluruh dunia setiap tahun dan $80 \%$ terjadi pada negara-negara dengan pendapatan perkapita rendah hingga sedang. Menurut WHO, pada akhir abad ini rokok akan membunuh lebih dari satu miliar orang jika tidak ada usaha untuk menanggulanginya. Oleh karena itu, WHO membentuk WHO Framework Convention on Tobacco Control (WHO-FCTC) menyediakan solusi untuk masalah epidemi tembakau yang telah mendunia. Hingga saat ini, WHO terus mendorong masyarakat agar berhenti merokok untuk mengurangi bahaya tembakau dengan berbagai metode, salah satunya adalah menggunakan NRT atau Nicotine Replacement Therapy (terapi pengganti nikotin) (WHO, 2009). 
NRT adalah metode yang menggunakan suatu media untuk memberikan nikotin yang diperlukan oleh perokok tanpa pembakaran tembakau yang merugikan. Walaupun NRT hanya ditujukan untuk menghilangkan pembakaran tembakau dan sebagai sarana alternatif pemberian nikotin tetapi pada prakteknya sering dipakai sebagai alat bantu dalam program berhenti merokok (smoking cessation program) untuk mencegah withdrawal effect nikotin dengan cara menurunkan dosis nikotin secara bertahap. Terdapat beberapa macam NRT, salah satunya yaitu electronic cigarette atau rokok elektronik. Rokok elektronik merupakan salah satu NRT yang menggunakan listrik dari tenaga baterai untuk memberikan nikotin dalam bentuk uap dan oleh WHO disebut sebagai electronic nicotine delivery system (ENDS) (William $\mathrm{dkk}, 2010)$.

Rokok konvensional maupun rokok elektrik mengandung berbagai macam zat adiktif yang dapat menimbulkan kecanduan dan merupakan faktor risiko terhadap berbagai penyakit seperti penyakit jantung, stroke, penyakit paru, berbagai jenis kanker terutama kanker paru dan mulut, impotensi, gangguan kehamilan dan janin. Selain berdampak buruk terhadap kesehatan, rokok juga mempunyai dampak yang besar terhadap kerugian ekonomi. Total kerugian negara per tahun akibat produk tembakau mencapai Rp. 338,75 triliun sedangkan pendapatan dari cukai rokok hanya sebesar Rp. 53,9 triliun (Kosen, 2012).

Dari tahun ke tahun jumlah perokok di dunia semakin meningkat. Begitu pula di Indonesia, yang merupakan negara dengan jumlah perokok terbesar ke-3 di dunia. Berdasarkan laporan WHO terbaru tahun 2011 prevalensi perokok usia 10 tahun ke atas di Indonesia sebesar 46,8\% pada laki-laki dan 3,1 pada perempuan, dengan jumlah perokok mencapai 62,8 juta dimana 40 persen di antaranya berasal dari kalangan sosial ekonomi rendah (WHO, 2011). Data Riset Kesehatan Dasar (Riskesdas) tahun 2007 diketahui bahwa prevalensi penduduk umur lebih dari atau sama dengan 10 tahun yang merokok sebesar 29,2\% dimana $81,2 \%$ diantaranya merokok setiap hari dan $85,4 \%$ merokok di dalam rumah bersama anggota keluarga yang lain. Pada tahun 2010 prevalensi perokok meningkat menjadi $34,7 \%$ dimana $81,3 \%$ diantaranya merokok setiap hari.

Salah satu penyebab dalam meningkatnya prevalensi merokok pada remaja di Indonesia karena kurangnya pemahaman mereka tentang bahaya rokok dan 
terjebaknya mereka pada mitos-mitos menyasatkan tentang rokok. Berdasarkan Global Youth Tobacco Survei (GYTS) tahun 2009 30.4\% anak sekolah usia 13 15 tahun pernah merokok, 57,8\% pada laki-laki dan $6,4 \%$ pada perempuan. Selain itu diketahui $20.3 \%$ anak sekolah usia 13 - 15 tahun adalah perokok aktif, 41\% pada laki-laki $41 \%$ dan $3.5 \%$ pada perempuan.

Untuk itu pencegahan dan penanggulangan perilaku merokok pada remaja sangat penting untuk memutus generasi perokok pemula. Jika perokok pemula dikalangan remaja bisa dicegah dan para perokok tua akan berhenti baik karena sadar maupun sakit maka jumlah perokok berangsur angsur akan menurun. Selain itu upaya pencegahan perilaku merokok pada remaja baik konvensional maupun elektrik sangat penting dalam menyiapkan sumber daya manusia, generasi penerus bangsa yang berkualitas. Agar dapat melakukan pencegahan perilaku merokok baik konvensional maupun elektrik maka sangat penting diketahui apa sajakah faktor yang memengaruhi.

Penelitian ini bertujuan untuk mengetahui faktor yang memengaruhi merokok elektrik pada siswa SMA swasta di kota Denpasar.

\section{METODE}

Penelitian ini adalah penelitian yang bersifat observasional dengan rancangan yang digunakan untuk mengetahui pengaruh variabel bebas dengan variabel tergantung adalah cross-sectional study. Pengambilan data pada penelitian ini dilaksanakan di SMA swasta di wilayah Kota Denpasar, Provinsi Bali selama 3 bulan dari Bulan Januari sampai dengan Bulan Maret Tahun 2017. Populasi penelitian ini adalah siswa SMA swasta di Kota Denpasar. Dalam pengambilan sampel peneliti menggunakan simple random sampling. Pengumpulan data menggunakan angket data yang dikumpulkan akan dianalisis secara univariat, bivariat dan multivariat.

\section{HASIL}

Berdasarkan hasil penelitian rata-rata umur subyek adalah 16 tahun dan semuanya berjenis kelamin laki-laki. Proporsi siswa yang pernah mencoba-coba menggunakan rokok elektrik sebesar 41,38 \% (72 orang) dan yang tetap atau aktif 
merokok elektrik sebesar 25,29\% (44 orang). Berdasarkan hasil analisis, faktorfaktor yang mempengaruhi merokok elektrik pada Siswa SMA swasta di Denpasar adalah siswa yang tidak percaya merokok berbahaya terhadap kesehatan berpeluang 2,8 kali untuk merokok elektrik secara aktif dibandingkan yang percaya $(95 \%$ CI 1,6-4,8). Siswa yang mempunyai keluarga merokok berpeluang 2,5 kali untuk merokok elektrik dibandingkan yang tidak punya, serta siswa yang mempunyai teman merokok berpeluang 2,6 kali untuk merokok elektrik dibandingkan yang tidak punya.

Tabel 1. Pengaruh Sikap Terhadap Perilaku Merokok Pada Siswa Di Sekolah Menengah Atas Saraswati 1 Denpasar Tahun 2017

\begin{tabular}{lcccc}
\hline \multirow{2}{*}{ Keyakinan remaja } & \multicolumn{2}{c}{ Aktif merokok elektrik } & PR & \\
& Ya & Tidak & $(95 \% \mathrm{CI})$ & Nilai p \\
\hline Tidak, $\mathrm{n}(\%)$ & $7(63,6)$ & $4(36,4)$ & 2,8 & $<0,001$ \\
Ya, $\mathrm{n}(\%)$ & $37(22,7)$ & $126(77,3)$ & $1,649-4,765$ & \\
\hline
\end{tabular}

Tabel 2. Pengaruh Role Model Orang Tua Terhadap Perilaku Merokok Pada Siswa Di Sekolah Menengah Atas Saraswati 1 Denpasar Tahun 2017

\begin{tabular}{lcccc}
\hline & & & & \\
Mempunyai keluarga merokok & Aktif merokok elektrik & PR & Nilai p \\
& & & & \\
& Ya & Tidak & & \\
\hline Tidak, $\mathrm{n}(\%)$ & $27(39,7)$ & $41(60,3)$ & 2,5 & $<0,001$ \\
Ya, $\mathrm{n}(\%)$ & $17(16,0)$ & $89(84,0)$ & $1,463-4,191$ & \\
\hline
\end{tabular}

Tabel 3. Pengaruh Teman Sebaya Terhadap Perilaku Merokok Pada Siswa Di Sekolah Menengah Atas Denpasar Tahun 2017

Mempunyai teman merokok

Aktif merokok elektrik

Ya Tidak $\quad(95 \% \mathrm{CI})$ 


\begin{tabular}{lcccc}
\hline Tidak, $\mathrm{n}(\%)$ & $4(11,1)$ & $32(88,9)$ & 2,6 & $<0,001$ \\
Ya, n(\%) & $37(29,1)$ & $90(70,9)$ & $2,365-2,907$ & \\
\hline
\end{tabular}

\section{DISKUSI}

Hasil analisis menunjukkan bahwa sebagian besar siswa yang pernah mencoba-coba merokok akhirnya menjadi perokok elektrik aktif. Hal ini juga menujukkan bahwa perilaku merokok tinggi dikalangan siswa dan diawali dengan perilaku coba-coba.

Berdasarkan tabel 1. diatas didapatkan bahwa Siswa yang tidak percaya merokok berbahaya terhadap kesehatan berpeluang 2,8 kali untuk merokok elektrik secara aktif dibandingkan yang percaya. Dengan kata lain ada pengaruh yang signifikan antara sikap terhadap perilaku merokok pada siswa laki- laki di Sekolah Menengah Atas di Kota Denpasar. Sikap belum merupakan suatu suatu tindakan atau aktifitas, akan tetapi merupakan predisposisi tindakan suatu perilaku. Sikap itu masih merupakan reaksi tertutup, bukan merupakan reaksi terbuka. Sikap merupakan kesiapan untuk bereaksi terhadap objek dilingkungan tertentu sebagai suatu penghayatan terhadap objek (Notoatmodjo, 2010). Sikap tidak selalu konsisten dengan perilaku karena antara sikap dan perilaku ada faktor penghubung yaitu niat, dan niat itu sendiri dipengaruhi banyak hal, baik dari dalam diri sendiri maupun karena faktor luar, misalnya tekanan sosial. Sikap juga dipengaruhi oleh kepercayaan. Apabila seseorang, dalam hal ini tidak percaya (baik dari hasil pengamatan ataupun informasi yang diterima) bahwa merokok berbahaya bagi kesehatan, maka kemungkinan remaja untuk berperilaku merokok adalah besar. Sikap adalah salah satu variabel yang mempengaruhi perilaku dan masih banyak variabel lain yang juga berpengaruh terhadap timbulnya suatu perilaku. Kar dalam Notoatmodjo (2003) menganalisis perilaku dengan bertitik tolak bahwa perilaku itu merupakan fungsi dari niat untuk bertindak (behavior Intention), dukungan sosial dari masyarakat sekitar (acessbility of Information), otonomi pribadi dalam pengambilan keputusan atau tindakan (Personal Autonomy), dan situasi yang menungkinkan untuk bertindak (Action Situation). Dari literatur dan hasil penelitian yang ditemui, peneliti berasumsi bahwa sikap 
seseorang mempengaruhi perilaku orang tersebut. sikap yang ditimbulkan terhadap perilaku merokok akan mempengaruhi individu tersebut dalam mengambil keputusan untuk berperilaku merokok.

Berdasarkan tabel 2 diatas didapatkan bahwa Siswa yang mempunyai teman merokok berpeluang 2,6 kali untuk merokok elektrik secara aktif dibandingkan yang tidak punya. Dengan kata lain ada pengaruh yang signifikan antara teman sebaya terhadap perilaku merokok pada siswa laki- laki di Sekolah Menengah Atas di Kota Denpasar. Berdasarkan penelitian ini diketahui sebagian besar responden mengenal atau memiliki kebisaan merokok karena pengaruh teman-teman. Hal ini karena remaja memiliki hasrat berkelompok dengan kawan senasib dan sebaya, dorongan sosial dari lingkungan yang mendesak remaja untuk merokok atau kalau tidak merokok dianggap tidak solider dengan lingkungan sosialnya.

Berdasarkan tabel 3 diatas didapatkan bahwa siswa yang mempunyai keluarga merokok berpeluang 2,5 kali untuk merokok elektrik secara aktif dibandingkan yang tidak punya. Dengan kata lain ada pengaruh yang signifikan antara role model orang tua terhadap perilaku merokok pada siswa laki- laki di Sekolah Menengah Atas saraswati 1 Denpasar. Remaja perokok adalah anak-anak yang berasal dari rumah tangga yang tidak bahagia, dimana orang tua tidak begitu memperhatikan anak-anaknya dibandingkan dengan remaja yang berasal dari lingkungan rumah tangga yang bahagia. Remaja yang berasal dari keluarga konservatif akan lebih sulit untuk terlibat dengan rokok maupun obat-obatan dibandingkan dengan keluarga yang permisif, dan yang paling kuat pengaruhnya adalah bila orang tua sendiri menjadi figur contoh yaitu perokok berat, maka anak-anaknya akan mungkin sekali untuk mencontohnya (Baer \& Corado). Berdasarkan penelitian dan literature yang didapat diketahui sebagian besar responden mengenal atau memiliki kebisaan merokok karena pengaruh role orang tua.

\section{SIMPULAN}

Perilaku merokok elektrik secara aktif pada siswa SMA swasta di Denpasar tergolong tinggi. Ketidakpercayaan terhadap bahaya rokok terhadap 
kesehatan, adanya keluarga dan teman yang merokok terbukti sebagai faktor. Untuk itu penting edukasi yang dapat meyakinkankan mereka tentang bahaya rokok elektrik dan intervensi melalui pendekatan keluarga serta teman sebaya.

\section{ACKNOWLEDGEMENT}

Terima kasih yang sebesar-besarnya kepada STIKES Wira Medika Bali, SMA Swasta di Denpasar dan semua surveyor yang telah bekerja keras dalam pengumpulan data.

\section{DAFTAR PUSTAKA}

American Legacy Foundation, (2009) Electronic cigarette ("e-cigarette") Fact Sheet..Diakses.tanggal.19-10-2010, http://www.americanlegacy.org/PDFPublications/ElectronicCigarette FactS heet.pdf

Amstrong. 1990. Management Sumber Daya Manusia.Jakarta: PT Gramedia Aritonang, MER. 1997. Skripsi Fenomena Wanita Merokok. Yogyakarta: UGM

Atkinson,dkk. 1997. Pengantar Psikologi. Diterjemahkan Dr. Widjaja Kusuma. Batam: Interaksara.

Bart,Smet. 1994. Psikologi Kesehatan. PT. Gramedia Widisarana Indonesia BBKBN. 2009. Harapan Hidup pada 2019. http://www.bkkbn.go.id, diakses 29 April 2014.

Hurlock, Elizabeth, B. (1999). Psikologi Perkembangan: “ Suatu Pendekatan Sepanjang Rentang Kehidupan" (Terjemahan Istiwidayanti \& Soedjarno). Jakarta: Penerbit Erlangga.

http://www.mqmedia.com/tabloid_mq/apr03/mq_remaja_pernik.htm [on-line]. http://www.proquest.com/ [on-line].

Kemenkes RI, Badan Penelitian dan Pengembangan Kesehatan 2008, Laporan Nasional Riset Kesehatan Dasar 2007, Jakarta.

Kemenkes RI, Badan Penelitian dan Pengembangan Kesehatan 2011, Laporan Nasional Riset Kesehatan Dasar 2010, Jakarta. 
Kosen S, 2012. Current Burden and Economic Costs of Major Tobacco Attributed Diseases in Indonesia. Presented at The World Conference on Tobacco or Health (WCTOH) 2012, Sdafingapore 20-24 march 2012.

Komasari, D. \& Helmi, AF. (2000). Faktor-Faktor Penyebab Perilaku Merokok Pada Remaja. Jurnal Psikologi Universitas Gadjah Mada, 2. Yogyakarta: Universitas Gadjah Mada Press.

Levy, M.R. (1984). Lyfe and Health. New York: Random House.

Mc Gee, dkk. (2005). Is Cigarette Smoking Associated With Suicidal Ideation Among Young People? : The American Journal of Psychology. Washington.

Monks, FJ \& Knoers, AMP, Haditono, (1999). Psikologi Perkembangan : Pengantar Dalam Berbagai Bagiannya, (Terjemahan Siti Rahayu Haditono). Yogyakarta: Gadjah Mada University Press.

Mu'tadin, Z. (2002). Kemandirian Sebagai Kebutuhan Psikologis Pada Remaja. http://www.e-psikologi.com/remaja.050602.htm [on-line].

Notoatmodjo S. 2007. Kesehatan Masyarakat Ilmu dan Seni. Jakarta: Rineka Cipta.

Notoatmodjo S. 2007. Kesehatan Masyarakat Ilmu dan Seni. Edisi Revisi 2011. Jakarta: Rineka Cipta.

Ogden, Jane. (2000). Health Psychology. Buckingham : Open University Press.

Oskamp, Stuart. (1984). Applied Social Psychology. New Jersey : Prentice Hall.

Remaja dan Rokok. 2002. http://www.e-psikologi.com/remaja.050602.htm [online].

Sarafino.1994.Health Psycology.New York:John Wiley \& Sons,Inc.

Sarwono, SW. 2004. Psikologi Remaja, Raja Grafindo Persada : Jakarta

Sitepoe.2001. Kekhususan Rokok Indonesia.Jakarta : Gramedia Widiasarana Indonesia

Walgito, B 1991. Pengantar Psikologi Umum, Edisi Revisi, Cetakan keempat, Jogjakarta:Andi Offset

Welfare.Available from:http://www.aafa.org/display.cfm?id=9\&sub=42\#_ftn4.Diakses Pada tanggal 01 Januari 2015 
Westenberger, B.J. (2009) Evaluation of e-cigarettes. department of health \& human services food and drug administration, center of drug evaluation and research division of pharmaceutical analysis,1-8.Diakses.tanggal.19-102010, www.fda.gov/downloads/drugs/scienceresearch/UCM173250.pdf

WHO (World Health Organisation) (2011). WHO Report on the Global Tobacco Epidemic, 2011. Accessed 11 December Available from: http://whqlibdoc.who.int/publications/2011/9789240687813 eng.pdf 